\title{
Genetic polymorphism of merozoite surface protein-1 (MSP-1) block 2 allelic types in Plasmodium falciparum field isolates from mountain and coastal area in West Sumatera, Indonesia
}

\author{
Nuzulia Irawati \\ Department of Parasitology, Medical Faculty of Andalas University, Padang, Indonesia
}

\begin{abstract}
Abstrak
Latar belakang: Sampel P. falciparum dari lapangan dapat menampilkan bentuk dan jenis yang bervariasi. Penelitian ini bertujuan mengetahui keragaman alel MSP-1 blok 2 isolat P. falciparum yang berasal dari daerah pegunungan dan daerah pantai Sumatera Barat, Indonesia dan membandingkan keberadaan jenis-jenis alel dari kedua daerah pegunungan dan pantai.
\end{abstract}

Metode: 56 sampel darah yang terinfeksi P. falciparum, diperoleh dari 27 penderita yang berobat pada Puskesmas di Kabupaten Solok Selatan yang merupakan daerah pegunungan dan 29 penderita yang datang berobat pada Puskesmas dari daerah pantai di kabupaten Pesisir Selatan, Sumatera Barat, Indonesia. Daerah-daerah yang mengapit sifat-sifat yang sangat polimorfik, blok 2 MSP-1, ditentukan genotipnya melalui allele-specific nested PCR guna menganalisa populasi kepadatan parasit. Analisis urutan daerah-daerah polimorfik dari MSP-1 juga dilakukan untuk mengidentifikasi keanekaragaman alel di dalam populasi parasit.

Hasil: Polimorfisme alel yang beranekaragam dari MSP-1 diidentifikasi pada isolat P. falciparum dari suatu daerah pegunungan dan daerah pantai di Sumatera Barat, Indonesia, dan kebanyakan infeksi ditemukan berupa infeksi campuran. Analisa urutan MSP-1 blok 2 mengungkapkan bahwa teridentifikasi 16 alel berbeda untuk MSP-1 (3 untuk tipe K1, 2 untuk tipe MAD20 dan 2 untuk tipe RO33).

Kesimpulan: Dari isolat lapangan P. falciparum yang dikumpulkan dari suatu daerah pegunungan dan daerah pantai di Sumatera Barat teridentifikasi polimorfifme genetik yang luas. Juga ditemukan tingkat infeksi campuran yang tinggi, sebagai derajat kemajemukan infeksi yang tinggi. (Med J Indones 2011; 20:11-4)

\begin{abstract}
Background: The field isolates of $P$. falciparum may display variant forms and different frequencies. This study was designed to know the diversity of allelic type of MSP-1 block 2 among P. falciparum isolates collected in a mountain and a coastal area in West Sumatera, Indonesia, and compare mountain and coastal area.

Methods: A total of 56 P. falciparum infected blood samples, collected from 27 patients attending local health facilities in South Solok district in a mountain region and 29 patients attending a local health facilities in South Coastal district region, West Sumatera, Indonesia were used in this study. The regions flanking the highly polymorphic characters, block 2 for MSP-1, were genotyped by allele-specific nested-PCR to analyse the population diversity of parasite. Sequence analysis of the polymorphic regions of MSP-1 was also conducted to identify allelic diversity in the parasite population.

Results: Diverse allelic polymorphism of MSP-1 was identified in P. falciparum isolates from a mountain area and a coastal area in West Sumatera, Indonesia, and most of the infections were determined to be mixed infections. Sequence analysis of MSP-1 block 2 revelaled that 16 different alleles for MSP-1 (3 for K1 type, 2 for MAD20 type and 2 for RO33 type) were identified.
\end{abstract}

Conclusion: Extensive genetic polymorphism with diverse allele type was identified in MSP-1 in P. falciparum field isolates from a mountain and a coastal area. A high level of mixed infections was also obcserved, as was a high degree of multiplicity of infection. (Med J Indones 2011; 20:11-4)

Key words: allelic types, coastal area, mountain area, MSP-1 block 2, Plasmodium falciparum

Genetic diversity displayed by $P$. falciparum field isolates, the occurence of variant forms of parasite at different frequencies in different geographic areas, and the complexity of infection represent major obstacles for the effective control of malaria. The propagation of multi-drug resistant parasites and insecticide-resistant mosquitoes has led to major difficulties in controlling the spread of malaria. To fight against malaria, an effective vaccine is urgently needed. ${ }^{1,2}$ A number of Correspondence email to: nuzulia.irawati@yahoo.com antigens expressed at different stages of parasite's life cycle have been characterized with respect to their use in vaccine development against $P$. falciparum. Merozoite surface protein-1 (MSP-1) is one of the most promising vaccine candidates. ${ }^{3}$ People naturally exposed to P. falciparum develop antibodies against MSP-1. Furthermore, an association between a naturally acquired immune response to MSP-1 and reduced malaria morbidity has been observed. In a number of independent studies, 
immunization with purified native MSP-1 or a recombinant fragment of protein has induced at least partial protection against parasite challenge. Sequence comparisons showed that the entire MSP-1 gene could be divided into 17 blocks that are vaiable, conserved, or semiconserved. ${ }^{4}$ In seven blocks $1,3,5,12$, and 17 , the sequences are conserved. In seven blocks (blocks 2,4,6,8,10, 14, and 16), the sequence show extensive diversity, while in the remaining (blocks 7,9,11,13, and 15), the sequence are semiconserved.Variation in sequences of variable regions are dimorphic (K1/Wellcome or $\mathrm{MAD}_{20}$ ) in nature with the exception of the trimorphicencoding region in block-2, which has a third version $\left(\mathrm{RO}_{33}\right)$ found in natural isolates. ${ }^{5,6}$ Naturally acquired antibodies react more frequently against variable rather than conservedMSP_1 blocks and are specific for one of the major version of variable blocks. ${ }^{7}$

In the current study, we have analyzed polymerase chain reaction (PCR)-amplified fragments containing variable blocks 2,4, and 12-16 of the MSP-1 gene in the $P$. falciparum natural population and allelic types were scored by sampling allele-specific radiolabeled olingonuclotide probes. The allelic types were compared among the isolates collected from regions of hyperendemic malaria transmission (RHEMT) and mesoendemic malaria transmission (RMEMT). ${ }^{8,9} \mathrm{We}$ have also analyzed the allelic diversity in the isolation showing more than strain of parasites.

\section{METHODS}

\section{Clinical samples}

The study was conducted in South Solok district, a area located in Bukit Barisan Mountain and in Pesisir Selatan, a area located in west coastal in West Sumatera province, Indonesia. The area has a farming of cocoa and sawit coconut in South Solok and majority was the fishing community in Pesisir selatan. All area is infested a primary vector, Anopheles balabacensis in South Solok and Anopheles sundaicus in Pesisir Selatan and is characterized by high altitude, relative high humidity, constant rain, and an average of temperature $23^{\circ} \mathrm{C}$, in South Solok, and coastal area, relative high humidity, constant rain, and an average of temperature $30^{\circ} \mathrm{C}$ in Pesisir Selatan. The analyzed samples were collected during an outbreak in which the prevalence of malaria was $60 \%$, measured as the percentage of people with parasites among those who presented with malaria symptoms at a health service.
The samples was collected by finger puncture in the form of thick smears on slides. The slides were stained with Giemsa, and the presence of $P$. falciparum was detected under microscopic observation. The slides were then sent to the Medical Faculty, Andalas University in Padang, and parasitemia was determined and normalixed for 100 leukocytes. This information was converted into the number of parasites per microliter, assuming a leucocyte count of $8,000 / \mu \mathrm{L}$. To prepare DNA of the clinical samples, the thick smear, moistened previously with $1 \%$ saponin, the incubated for one hour at $4^{\circ} \mathrm{C}$. The sample was centrifuged at $12,000 \mathrm{xg}$ for five minutes, and the supernatant discarded. The precipitate was resuspended in $40 \mu \mathrm{L}$ of Chelex-100 5\% and boiled for 10 minutes. Finally the sample was centrifuged at $12,000 \mathrm{xg}$ for five minutes, and the supernatant was recovered and stored at $4^{\circ} \mathrm{C} \cdot{ }^{10,11}$ We used $8 \mu \mathrm{L}$ of the extract to amplify the MSP-1 gene through polymerase cian reaction (PCR).

The first amplification were used as a template for respective nested PCR assays. We took $5 \mu \mathrm{L}$ to identify the allotypes in block 2 of MSP-1.

\section{Allotype detection in block 2 of MSP-1}

In the PCR-based amplification for MSP1 gene and the nested PCR to identify the allotypes in block 2 of this gene, we used an amplification profile with an initial denaturation at $94^{\circ} \mathrm{C} / 2 \mathrm{~min}$ followed by $72^{\circ} \mathrm{C} / 2 \mathrm{~min}$, time during which the Taq DNA Polymerase enzyme was added. Then, 35 cycles at $94^{\circ} \mathrm{C} / 30 \mathrm{sec}, 55^{\circ} \mathrm{C} / 30$ sec, and $72^{\circ} \mathrm{C} / 2$ min were performed, ending with a final extension at $72^{\circ} \mathrm{C} / 2 \mathrm{~min}$. The following primers were used in amplifying the MSP1 gene: OK11 )5' TAG AAG ATG CAG TAT TGA CAG GTT A 3') and OK12 (5' ATT CTA ATT CAA GTG GAT CAG TAA ATA A 3'). To define the allele present in block 2 of the MSP-1 gene, the primers OK1 (CTT AAA TGA AGA AGA AAT TAC TAC AAA AGG TGC 3') and OK2 (5', GAG GGC TTG CAC CAG ATG AAG T 3') were used for the $\mathrm{K} 1$ allelic type. The primers OK3 (5' GTA TTA AAT GAA GGA ACA AGT GGA ACA 3')and OK4 (5', TAT CTG AAG GAT TTG TAC GTC TTG AAT T 3') were used to typify the MAD20 allotype. The primers Primer-primer OK5(5', ATT AAA GGA TGG AGC AAA TAC TCA AFT TGT 3' and OK6 (5' TC GAA GGA TTT GCA GCA CCT GGA GA 3') were used to amplify the RO33 allelic type. Both the primary and the nmested PCR were conducted in a final volume of 50 $\mu \mathrm{L}$, using $200 \mu \mathrm{M}$ of each $\mathrm{dNTP}, 1 \mu \mathrm{M}$ of each primer, 2,5 $\mathrm{U}$ of TaqDNA polymerase (Promega) per reaction and $1, \mathrm{mM}$ of $\mathrm{MgCl}_{2}$ in the enzyme buffer $(50 \mathrm{mM} \mathrm{KCl}$, 10 mM Tris-HCl, $\mathrm{pH} 9.0,0,1 \%$ Triton $\mathrm{x} 100)$. 


\section{Allelic distribution and complexity of infection}

The prevalence of each allelic type analyzed was determined as the percentage of PCR fragments for the type in the total number of amplified bands for the corresponding locus. The complexity of infection, which is the average number of PCR bands per infected individual, was determined as described earlier. The percentage for type and complexity of infection were calculated independently for each genetic marker.

\section{RESULTS}

Of 56 samples analyzed from mountain area and coastal area, the endemic area in West Sumatera result in MSP1 was 14 peoples respectively. Genetic diversity was analyzed through PCR amplification of polymorphic regions in MSP1 gene. The three previously reported allelic types were found in block 2 of MSP1 from 28 samples were K1, MAD20, and RO33 type with the result as following: (Table 1)

Table 1. The result of the allelic amplification K1, MAD20, and RO33 of MSP1 gene of $P$. falciparum in mountain area and coastal area.

\begin{tabular}{lcc}
\hline Combined allelic types & Mountain area & Coastal area \\
\hline K1 & 0 & 2 \\
MAD20 & 0 & 0 \\
RO33 & 0 & 1 \\
K1,MAD20 & 3 & 7 \\
K1,RO33 & 0 & 0 \\
MAD20,RO33 & 1 & 0 \\
K1, MAD20, RO33 & 10 & 4 \\
\hline Total & 14 & 14 \\
\hline
\end{tabular}

These types were established on the basis of differences in size observed through electrophoresis and showed respective sizes of 99-147 bp, 110-136 bp, and 99-120 bp of K1, MAD20, and RO33 respectively. The allelic most often present in the parasite population of the samples in mountain area studied was MAD20, with the frequency of $36.84 \%$ ( 14 of 38 ), K1 $34.21 \%$ (13 of 38 ), and RO33 $28.94 \%$ (11 of 38 ). Similarly, the allelic most often present in the parasite population of the samples in coastal area studied was K1, with the frequency of $44.8 \%$ ( 13 of 29), MAD20 37.93\% (11 of 29), and RO33 17.24\% (5 of 29).

Table 2. Distribution of fragments length of K1 allele types

\begin{tabular}{lllll}
\hline \multirow{2}{*}{ Located } & \multicolumn{4}{c}{$\mathrm{K} 1$} \\
\cline { 2 - 5 } & $99 \mathrm{bp}$ & $120 \mathrm{bp}$ & $147 \mathrm{bp}$ & total \\
\hline Mountain area & 3 & 3 & 5 & 11 \\
Coastal area & 3 & 4 & 6 & 13 \\
\hline
\end{tabular}

Table 3. Distribution of fragments length of MAD20 allele types

\begin{tabular}{lccc}
\hline \multirow{2}{*}{ Located } & \multicolumn{3}{c}{ MAD20 } \\
\cline { 2 - 4 } & $110 \mathrm{bp}$ & $136 \mathrm{bp}$ & total \\
\hline Mountain area & 6 & 7 & 13 \\
Coastal area & 5 & 6 & 11 \\
\hline
\end{tabular}

Table 4 Distribution of fragments length of RO33 allele types

\begin{tabular}{lccc}
\hline Located & \multicolumn{3}{c}{ RO33 } \\
\cline { 2 - 4 } & $99 \mathrm{bp}$ & $120 \mathrm{bp}$ & total \\
\hline Mountain area & 6 & 5 & 11 \\
Coastal area & 5 & - & 5
\end{tabular}

\section{DISCUSSION}

The structure of natural $P$. falciparum population plays a highly important role in the natural acquisition of immunity in malarial infection. Knowledge of this structure is necessary to develop strategies to control the disease, beginning with the design of effective vaccines against $P$. falciparum and including policy on the use of antimalarial medicines. We analyzed the genetic diversity of $P$. falciparum isolates collected in mountain endemic area and in coastal endemic area in West Sumatera, Indonesia for malaria but one where there is no permanent transmission of the parasite, as in certain African zones.

From the result was known that there were three infection combinations in mountain area and four infection combinations in coastal area. This condition may be caused by both these study areas were the open areas for all the comers and result in chance to occur mutation to $P$. falciparum infection is very large that is genetic recombination and variable result. Although the mountain and the coastal area in West Sumatera is the low endemic area, in Sumatera allelic variation is highly. This is much the same to result obtained ih other region, such as Thailand ${ }^{12}$ and Senegal. ${ }^{13}$ The presence of novel variation is due to transmigration from other island in Indonesia to Sumatrera terrestrial is the important issue.

In this study is also found amount balance of K-type allele, MAD20-type allele, and RO33-type allele in their frequency. This condition is proven with other regions having geographical isolation. For example, the studies by Diana Gomez only find MAD20 and K-tyoe alleles, by fragment variance is restricted. Because there are in isolation areas in Colombia. ${ }^{14}$

In some same research in different geographic area than msp1 block 2 as a marker, report important 
variation in the genotype frequency. For example, in the other studies were found similar MAD20, K1, and RO33 allelic frequencies. This is highly different than the studies in France Guiana ${ }^{15}$ that only find a little MAD20-type allele and K1-allele type is plenty.

In this study is also found the fragment length of each allele. This variation and condition demonstrate the diverse MSP1 block 2 gene in each region, such that it can not as pattern to other regions. The geographic factor very determine diversity of MSP-1 gene.

When various genotypes to a locus-parasite specific is found in a host, the possibility cross-fertilization and meioitic recombination in vector mosquitoes rise. In some level, the genetic diversity is expected depend to the proportion of mixed infection and amount of clone per individu. The precence of mixed infection is one of prerequisite if the corss-fertilization is to produce new generation and enhance to diversity of parasite population.

\section{REFERENCES}

1. Contamin H. Fandeur T, Bonnefoy S, Skouri F, Ntoumi F, Mercereau-Puijalon O. PCR typing of field isolates of Plasmodium falciparum. J. Clin Microbiol. 1995; 33:944-51.

2. Zwetyenga J, Rogier, Spiegel A, Fontenille D, Trape JF, Mercereau-Pujialon O. A cohort study of Plasmodium falciparum diversity during the dry season in Ndiop a Senegalese village with seasonal, mesoendemic area. Trans R Soc Trop Med Hyg. 1999; 93:375-80.

3. Gardner MJ, Hall N, Fung Eula, White O, et al. Genome sequenced of the human malaria parasite Plasmodium falciparum. Nature 2000; 419: 498-511.

4. Tanabe K, Mackay M, Goman M, Scaife JG. Allelic dimorphism in a surface protein gen Of malaria parasite Plasmodium falciparum. J Med Biol. 1987; 195: 273-87

5. Kaneko O, Kimura M, Kawamoto F, Ferreira MU, Tanabe K. Plasmodium falciparum: allelic variation in the merozoite surface protein 1 gene in wild isolates from southern Vietnam. Exp. Parasitol. 1997; 86: 45-57.

6. Snewin VA, Herrera M, Sanchez G, ScherfA, Langley GHerrera S. Polymorphism of alleles of the merozoite surface antigen MSA1 and MSA2 in Plasmodium falciparum wild isolates from Colombia. Mol Biochem Parasitol. 1991; 49: 265-75.

7. Maitland K, Kyes S, Williams TN, Newbold CI. Genetic restriction of Plasmodium falciparum in an area of stable transmission: an example of island evolution. Parasitology 2000; 120:335-43.

8. Haddad D, Snounou G, Mattei D, Enamorado IG, Figueroa J, Stahl S, Berzins K. Limited genetic diversity of Plasmodium falciparum in field isolates from Honduras. Am J TropMed Hyg 1999; 60: 30-4.

9. Alger J, Acosta MC, Lozano C, Velasquez C, Labrada LA. Stained smears as a source of DNA. Mem Inst Oswaldo Cruz. 1996; 91: 589-91.

10. Edoh D, Mshinda H, Jenkins J, Burger M. Pyrimethamineresistant Plasmodium falciparum parasites among Tanzanian children: a facility-based study using the polymerase chain reaction. Am J Trop Med Hyg. 1997; 57: 342-7.

11. Snounou G, Zhu X, Siripooon N, Jarra W, Thaithong S, Brown $\mathrm{KN}$, Viriyakosol S. Biased distribution of msp1 and msp2 allelic variation in Plasmodium falciparum population In Thailand. Trans R Soc Trop Med Hyg. 1999; 93: 369-74.

12. Zwetyenga J, Rogier C, Tall A, Fontenille D, Snounou G, Trape JF, Mercereau-Pujialon O. No influence of age on infection complexity and allelic distribution in Plasmodium falciparum infectios in Ndiop, a Senegalese village with seasonal, mesoendemic area. Trans R Soc Trop Med Hyg. 1999; 93:375-80.

13. Gomez, D, Chaparro, J, Rubiano, C, Rojas, M.O., Wasserman M. Genetic diversity of Plasmodium falciparum fied samples from an isolated Colombian vilages. Am J Trop Med Hyg. 2002; 67(6), 611-6.

14. Ariey F, Chalvet W, Hommel D, Peneau C, Hulin A, Mercereau-Puijalon $\mathrm{O}$, et al. Plasmodium falciparum parasites in French Guiana: limited genetic diversity and high selfing rate. Am J Trop Med Hyg. 1999; 61: 978-85

15. Wasserman M, Contreras J, Pinilla G, Rojas MO, Paez A, Caminos E. Plasmodium falciparum : characterization of a 0.7-kbp, modertaely repetitive sequence. Exp Parasitol. 1995; 81: 165-71. 